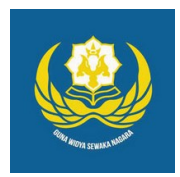

Jurnal Analogi Hukum

Journal Homepage: https://ejournal.warmadewa.ac.id/index.php/analogihukum

\title{
Pembantuan dalam Tindak Pidana Perjudian (Studi Putusan Nomor 94/Pid.B/2017/PN Gin)
}

\author{
I Nyoman Agus Suprapta*, I Ketut Sukadana dan I Made Minggu Widyantara \\ Universitas Warmadewa, Denpasar-Bali, Indonesia \\ *agussuprata@gmail.com
}

How To Cite:

Suprata I, N, A., Sukadana, I, K., Widyantara, I, M, M.(2020). Pembantuan dalam Tindak Pidana Perjudian (Studi Putusan Nomor 94/ Pid.B/2017/PN Gin). Jurnal Analogi Hukum. 2 (3). 278-282. Doi: https://doi.org/10.22225/ah.2.3.2491.278-282

\begin{abstract}
Gambling essentially is contrary to norms. In fact, gambling is increasingly done by people hide away or clearly. Other than gambling which has been well known and operated in some places in Indonesia, especially in bali like cock fighting, ceki(balinese card game), togel (black toto), bola adil and so on. Surely, it needs facilities and infrastructure to do that gambling. It makes willingness by an individual or a group of people to support to do gambling itself that giving chance to public for gambling. The problem in this research is how to regulate the assistance as one form of criminal act in Indonesia and how legal sanction done to the assistance in gambling criminal act that has been regulated on Number 94/Pid.B/2017/PN Gin. Research methods used in this research is normative research with the constitution and conceptual approach. After collecting all of legal materials, it will be processed and analyzed using legal argument, deductive inductive and formed descriptively into research. The result of this research can be concluded that the assistance as one of the form of criminal regulated in article 56 about the form of assistance, article 5 about assistance responsibility system and article 60 about assistance responsibility affirmation. The Judge, in giving legal sanction to the assistance suspect in gambling criminal act case number 94/Pid.B/2017/PN Gin. Has based on article 303 paragraph (1) point 2 KUHP in considering anything that relieving or burdening, case position, evidence of the witness and the suspect, and the Judge believes in giving a fair punishment.
\end{abstract}

Keywords: Assistance; Criminal Act; Gambling; Sanction

\begin{abstract}
Abstrak-Pada hakikatnya perjudian bertentangan dengan norma-norma. Namun pada kenyataannya, justru perjudian semakin marak dilakukan dengan cara sembunyi-sembunyi maupun secara transparan. Selain bentuk perjudian yang telah dikenal beroperasi di sejumlah tempat di Indonesia, khususnya di Bali seperti perjudian sambung ayam, ceki, toto gelap (togel), bola adil dan lainnya, tentunya membutuhkan sarana dan prasarana untuk melangsungkan perjudian tersebut. Sehingga timbulah niat seseorang atau lebih untuk memberikan pembantuan untuk melangsungkan perjudian tersebut yang memberi kesempatan kepada khalayak umum untuk bermain judi. Permasalahan dalam penelitian ini adalah bagaimanakah pengaturan pembantuan sebagai salah satu bentuk tindak pidana di Indonesia dan Bagaimanakah sanksi pidana terhadap pelaku pembantuan dalam tindak pidana perjudian dalam Putusan Nomor 94/Pid.B/2017/PN Gin. Metode penelitian yang digunakan adalah metode penelitian Normatif, dengan melakukan pendekatan perundang-undangan dan pendekatan konseptual. Setelah bahan hukum terkumpul, kemudian diolah dan dianalisis dengan menggunakan argumentasi hukum, deduktif-induktif, dan dituangkan secara deskriptif dalam bentuk penelitian. Hasil penelitian dapat disimpulkan bahwa pembantuan sebagai salah satu bentuk tindak pidana diatur dalam Pasal 56 mengenai bentuk dari pembantuan, Pasal 57 mengenai sistem pertanggungjawaban pembantuan, dan Pasal 60 mengenai penegasan pertanggungjawaban pembantuan. Hakim dalam memberikan sanksi pidana terhadap pelaku pembantuan dalam tindak pidana perjudian dengan nomor perkara 94/Pid.B/2017/PN.Gin sudah sesuai Pasal 303 ayat (1) butir 2 KUHP dengan mempertimbangkan hal-hal yang meringankan maupun memberatkan, posisi kasus, keterangan saksi dan terdakwa, dan keyakinan hakim dalam memberikan hukuman yang pantas.
\end{abstract}

Kata kunci: Pembantuan; Tindak Pidana; Perjudian, Sanksi 


\section{Pendahuluan}

Penegak hukum dalam mencegah dan meminimalisir perjudian sebagai tindakan yang menyimpang harus terus dilakukan. Hal ini sangat beralasan karena ancaman dari tindakan perjudian dapat menimbulkan ketegangan maupun ancaman nyata yang dapat menghambat pembangunan nasional dan terhadap norma-norma. Tindakan perjudian dapat membentuk watak individu menjadi pemalas sehingga mendidik individunafkahdari hasil yang tidak sewajarnya. Perjudian merupakan salah satu bentuk kejahatan yang dalam proses sejarah hingga perkembangannya sangat susah diberantas (Ebenezer et al., 2019). Manusia dalam kehidupan sehari-harinya sering dihadapkan pada keperluan yang mendesak, keperluan yang memuaskan individu, terkadang kebutuhan itu timbul dari keinginan atau desakan untuk bertahan. Secara umum keperluan setiap manusia dapat terpenuhi walau tidak sepenuhnya, dalam situasi yang tidak membutuhkan desakan dari diri sendirimaupun orang lain. Untuk memenuhi keperluan yang terdesak, biasanya terkadang dilakukan tanpa pikiran yang tenang dan matang sehingga dapat menganggu lingkungan sekitar (Djamali, 2014).

Sejak dulu hingga sekarang fenomena perjudian sudah ada dan praktik perjudian bukan lagi sesuatu yang asing di dalam kehidupan lingkungan sekitar. Praktik perjudian ini terjadi dipengaruhi oleh beberapa hal, diantaranya factor sosial dan ekonomi yang mempunyai peranan atas perkembangan praktik perjudian. perbuatan judi ini dianggap sebagai kejahatan karena melanggar norma sosial, agama didalam masyrarakat (Ikhsan, 2015). Perjudian berkembang dengan pesat dan semakin marak dilakukan. Tindakan yang konsisten terus dilakukan dalam menindakkin praktik perjudian, serta merupakan sebuah bukti dari kesungguhan aparat yang berwenang dalammeminimalisir praktik perjudian ("Perjudian," 2018). Selain perjudian yang diketahuiyang dilakukan di beberapa tempat di Indonesia, khususnya di Bali seperti perjudian sambung ayam, ceki, toto gelap (togel), bola adil dan lainnya, tentunya membutuhkan suatu sarana dan prasarana untuk berlangsungnya perjudian tersebut. Sehingga timbulah niat seseorang atau lebih dari satu orang untuk menyediakan tempat berlangsungnya perjudian tersebut yang memberi kesempatan kepada khalayak umum untuk bermain judi.

Terutama bagi yang membantu menyediakan sarana dan prasarana dalam melangsungkan perjudian. Dikarenakan bagi yang memberikan pembantuan dalam menyediakan sarana dan prasarana tentunya memudahkan melangsungkan perjudian tersebut. Sehingga mengganggu ketertiban umum disekitarnya. Selain itu dengan melakukan pembantuan dalam hal menyediakan sarana dan prasarana untuk bermain judi merupakan salah satu yang mudah untuk mendapatkan uang karena dengan menyediakan sarana dan prasarana ada sesuatu yang harus dibayar terlebih dahulu oleh peminat judi untuk bisa mendapatkan kesempatan bermain judi dan tentunya peminat judi ini tidaklah sedikit melihat maraknya perjudian di Indonesia, serta pemberi pembantuan ini bisa turut serta untuk bermain judi. Melihat lemahnya pengawasan, penegakan serta penerapan sanksi oleh oknum penegak hukum yang membuat masyarakat tidak takut melawan hukum salah satunya untuk memberikan pembantuan dalam melangsungkan praktik perjudian.

Dari uraian latar belakang masalah di atasdidapat 2 (dua) rumusan permasalahan yang akan dibahas, yaitu:

Bagaimanakah pengaturan pembantuan sebagai salah satu bentuk tindak pidana di Indonesia?

Bagaimanakah sanksi pidana terhadap pelaku pembantuan dalam tindak pidana perjudian dalam Putusan Nomor 94/Pid.B/2017/ PN Gin?

\section{Metode}

Tipe penelitian yang digunakan dalam dalam melakukan penelitian, yaitu Penelitian Hukum Normatif.Berdasarkan tipe penelitian hukum yang digunakan, yaitu normatif maka tipe pendekatan masalah yang digunakan dalam penelitian ini adalah pendekatan perundangundangan (statute approach) dan pendekatan konseptual (conceptual approach). Dalam menyusun penelitian ini, akan menggunakan bahan hukum yang diperoleh dari penelitian kepustakaan (library research), yaitu:

Sumber Bahan Hukum Primer yang terdiri dari peraturan tentang penertiban perjudian yang berlaku di Indonesia, yaitu Undangundang Republik Indonesia Nomor 7 tahun 1974 tentang penertiban perjudian, Peraturan Pemerintah Nomor 9 Tahun 1974 tentang Pelaksanaan Penertiban Perjudian, Kitab Undang - undang Hukum Pidana, serta putusan pengadilan.

Bahan Hukum Sekunder, yaitu memberikan penjelasan mengenai bahan hukum primer, misalnya wawancara, buku ilmu 
hukum.

Bahan Hukum Tersier yang digunakan dalam penelitian yang terdiri atas buku teks bukan hukum yang berkaitan dengan penelitian. Adapun bahan hukum tersier yang digunakan dalam penelitian ini, yaitu Kamus Besar Bahasa Indonesia (KBBI).

Teknik dalam pengumpulan bahan hukum yang digunakan dalam peneliti ini adalah teknik dokumentasi yang dilaksanakan dengan cara menginventarisasi dan mengkatagorisasi bahan hukum baik berupa peraturan perundangundangan, literatur-literatur maupun bahan hukum lainnya yang berkaitan dengan pembantuan dalam tindak pidana dan tindak pidana perjudian. Selanjutnya, dilakukan metode pencatatan, meringkas, mengulas sesuai dengan pokok masalah.

Analisis bahan hukum yaitu apabila seluruh bahan-bahan hukum yang dibutuhkan sudah terkumpul, kemudian diolah dan dianalisis, dengan menggunakan argumentasi hukum, deduktif -induktif, dan dituangkan secara deskriptif dalam bentuk skripsi.

\section{Hasil Penelitian dan Pembahasan}

\section{Pengaturan Pembantuan Sebagai Salah Satu Bentuk Tindak Pidana Di Indonesia}

Sebelum membahas tentang pengaturan pembantuan sebagai salah satu bentuk tindak pidana di Indonesia terlebih dahulu harus kita ketahui tentang Tindak Pidana itu sendiri. Dalam bahasa Indonesia, tindak pidana merupakan tindakan yang bisa atau dapat dihukum. Di dalam bahasa Belanda disebut "Strafbaarfeit". Istilah lain yaitu "delict" selain menggunakan istilah"strafbaarfeit". Istilah"delict" kemudian diterjemahkan dengan "delik" tentunya dengan adanya kesepakatan sebelumnya.Terjemahan strafbaarfeit menimbulkan berbagai arti yang diberikan oleh para ahli hukum, salah satunya Moeljatno misalnya menggunakan istilah tindak pidana dengan menyebutnya sebagai "perbuatan pidana", yaitu "suatu tindakan manusia yang dapat menimbulkan akibat hukum tertentu yang dilarang oleh undang-undang dimana pelakunya dapat dikenakan sanksi pidana" (Prasetyo, 2016).

Menurut Van Hamel, suatu tindakan yang secara tegas dilarang dan diancam pidana oleh suatu Undang-undang belum tentu merupakan tindak pidana (Ariman \& Raghib, 2015). Sebuah perbuatan tidak bisa begitu saja dikatakan perbuatan pidana. Oleh karena itu, harus mengetahui unsur-unsur yang terdapat dari perbuatan pidana. Adapun unsur formil yang terdapat dalam tindak pidana, yaitu harus ada perbuatan dari siri seseorang, perbuatan tersebut bertentangan dengan hukum yang berlaku, melawan hukum, dilakukan oleh orang yang bersalah, dan orang tersebut dapat dipertanggungjawabkan. Selain itu, adapun unsur material dari tindak pidana bersifat bertentangan dengan hukum yang berlaku. Apabila tidak bersifat melawan hukum tetapi perbuatan itu memenuhi rumusan dari undangundang, maka perbuatan itu bukan merupakan suatu tindak pidana.

Salah satu perbuatan tindak pidana, yaitu pembantuan dimana pembantuan dalam kejahatan adalah perbuatan yang sengaja memberi bantuan berupa saran, informasi atau kesempatan pembantu kepada orang lain yang melakukan tindak pidana. Medeplichtige oleh Utrecht menerjemahkan dengan istilah membantu, oleh Satochid Kartanegara menerjemahkan dengan istilah membantu melakukan, oleh Tirtaamidjaja menerjemahkan dengan istilah membantu melakukan pelanggaran tindak pidana, oleh P.A.F Lamintang menerjemahkan dengan istilah membantu melakukan tindak pidana (Marpaung, 1991). Tujuan dari dilakukannya pembantuan untuk mempermudah atau memperlancar pelaksanaan kejahatan yang dilakukan oleh pelaku atau pembantu.Suatu tindakan dapat disebut sebagai pembantuanbila memuat unsur-unsur berupa unsur subjektif dimana kesengajaan pembantu kejahatan dalam mewujudkan perbuatan bantuannya, baik sebelum pelaksanaan maupun pada saat pelaksanaan, dan unsur objektif dimana wujud dari perbuatan (bantuan) yang dilakukan oleh pembuat pembantu hanyalah bersifat mempermudah atau memperlancar pelaksanaan kejahatan (https://www.hukumonline.com/ klinik/detail/lt519a34bca3574/perbedaan-turutmelakukan-dengan-membantu-melakukan-

tindak-pidana/). Sehingga dari wujud perbuatan pembuat pembantu itu, tidaklah dapat menyelesaikan kejahatan, yang menyelesaikan kejahatan itu adalah wujud perbuatan yang dilakukan oleh pembuat pelaksananya.

Didalam pembantuan terdapat dua pihak yang terdiri dari dua orang atau lebih, yaitu pelaku atau pembuat (de hoofd dader) dan pembantu (de medeplichtige).Mengenai pembantuan termuat dalam tiga pasal, yaitu pasal 56, 57, dan 60 KUHP. Di dalam Pasal 56 KUHP mengatur mengenai bentuk dari pembantuan, yaitu pembantuan sebelum 


dan pada saat pelaksanaan

kejahatan.Sedangkan pasal 57 merumuskan tentang sistem pertanggungjawaban bagi pembantuan kejahatan. Kemudian, menurut pasal 60 KUHP mengatur mengenai penegasan pertanggungjawaban pembantuan itu hanyalah pada pembantuan dalam melakukan kejahatan yang dapat dipidana, sedangkan dalam membantu melakukan pelanggaran tidak dipidana.

\section{Sanksi Pidana Terhadap Pelaku Pembantuan Dalam Tindak Pidana Perjudian Dalam Putusan Nomor 94/Pid.B/2017/PN Gin}

Perjudian merupakan bentuk penyakit masyarakat, satu bentuk patologi sosial (Kartono, 2015). Perjdudian memiliki dampak negatif terhadap masyarakat terutama bagi generasi muda, karena merusak moral dan mental. Di sisi lain judi adalah masalah sosial yang sulit ditanggulangi dan sejak awal peradaban manusia judi sudah ada (Burlian, 2016). Perjudian adalah permaian yang menggunakan uang atau materiil sebagai taruhan dalam permainan dengan maksud untuk mendapat keuntungan yang bersifat untunguntungan yang tidak hanya didasarkan atas kepintaran sajatetapi atas dasar keuntungan yang lebih dominan. Praktik perjudian merupakan salah satu praktik yang sulit diminimalisir, karena disisi lain merupakan kebiasaan maupun cara untuk mendapatkan uang dengan mudah sekaligus mendapatkan kesenangan. Bagi mereka atau pelaku yang dengan sengaja memberikan kesempatan bermain judi, maka pelaku tersebut akan dijerat pasal 303 KUHP. Tetapi bagi pelaku yang ikut serta dalam bermain judi, maka pelaku itu akan dijerat pasal 303 bis KUHP. Namun, sebelum memberikan sanksi tentu harus dilihat apakah telah memenuhi unsur dari perjudian. (I Nengah Astawa, S.H. selaku jaksa di Kejaksaan Negeri Denpasar, wawncara, 23 November 2018)

Kitab Undang-undang Hukum Pidana (KUHP) mengatur perjudian dalam Bab XIV Pasal 303 dan 303 bis, dimana perjudian sebagai kejahatan terhadap kesopanan. Dikarenakan perjudian merupakan kejahatan, sehingga praktiknya yang terjadi dalam masyarakat perlu untuk diberantas karena perbuatan tersebut dapat berisiko terhadap terganggungnya ketertiban dalam kehidupan masyarakat umum. Dari ketentuan dalam Pasal 303 KUHP permainan judi sebagai objek yang termuat di dalam pasal. Tetapi, dalam KUHP tidak menyebutkan dalam hal bentuk dari perjudian secara detail. Tidak semua permainan termasuk sebagai salah satu bentuk judi, karena hanya permaianan yang mempertaruhkan sesuatu yang bernilai dan keuntungannya didasarkan oleh keberuntungan yang tidak dapat direncanakan dan diperhitungkan.

Mengenai perjudian sebagai tindak pidana selain diatur dalam KUHP, perjudian juga diatur dalam Undang-Undang Nomor 7 Tahun 1974 tentang Penertiban Perjudian dan PP Nomor 9 Tahun 1981 tentang pelaksanaan Undang-Undang Nomor 7 Tahun 1974 tentang Penertiban Perjudian. Undang-undang tersebut bertujuan untuk menertibkan dan meminimalisir praktik perjudian yang terjadi dalam kehidupan masyarakat dengan cara melarang dan mencabut pemberian izin penyelenggaraan perjudian. Tentunya hal tersebut bertentangan dengan ketentuan dalam Pasal 303 bis ayat (1) butir 2 KUHP. Selain itu, pasal tersebut merupakan kolonial Belanda yang sudah tidak sesuai dengan keadaan di masyarakat. Sehingga ketentuan yang diatur dalam KUHP tersebut dikesampingkan. Dalam ketentuan UndangUndang Nomor 7 Tahun 1974 tentang Penertiban Perjudian tersebut merupakan penetapan sanksi pidana dan bentuk perumusan oleh pembentuk undang-undang sebagai kebijakan untuk kepentingan praktis bagi penegak hukum dalam menangani permasalahan praktik perjudian.

Adapun macam-macam perjudian menurut Peraturan Pemerintah Nomor 9 Tahun 1981 tentang Pelaksanaan Undang-Undang Nomor 7 Tahun 1974 tentang Penertiban Perjudian, yaitu Perjudian di Kasino (Bingo, Baccarat, Keno, Poker, Roulette, Blackjack, Craps), Perjudian di tempat-tempat keramaian (Bola Adil, Adu Ayam, Adu Sapi, Adu Kerbau, Lempar Bola, Adu Domba), dan Perjudian yang dikaitkan dengan alasan-alasan lain (Adu Sapi, Adu Ayam, Adu Kerbau, Karapan Sapi) (http:// lolke371.com/2018/04/10-permainan-di-

casino/). Tidak termasuk apabila kebiasaan yang bersangkutan berkaitan dengan upacara keagamaan dan sepanjang haltersebut bukan merupakan perjudian.Mengenai Pasal 1 ayat (2) Peraturan Pemerintah Nomor 9 Tahun 1981 tentang Pelaksanaan Undang - Undang Nomor 7 Tahun 1974 tentang Penertiban Perjudian menyebutkan yang dimaksud dengan pemberian izin dalam hal ini merupakan izin penyelanggaraan perjudian yang diberikan oleh Pemerintah Pusat maupun Pemerintah Daerah sesuai dengan kewenagan masing-masing.

Perjudian memang banyak marak terjadi, tetapi untuk bisa melangsungkan perjudian tersebut tentunya dibutuhkannya suatu sarana dan prasarana. Adapun pembantuan dalam 
perjudian dimana pelaku memberikan kesempatan maupun menawarkan kesempatan kepada khalayak umum untuk bisa melangsungkan permainan perjudian. Modus praktiknya tergolong sederhana dan rahasia, yaitu dengan menyediakan tempat dalam suatu rumah yang tidak membuat aparat penegak hukum curiga. Seperti yang dilakukan oleh salah satu pelaku pembantuan dalam tindak pidana perjudian, yaitu I NYOMAN SUKARMA Alias KARMA yang berdasarkan Surat Penetapan Hakim Pengadilan Negeri Gianyar Nomor: 94/Pid.B/2017/PN.GIN tanggal 07 Juni 2017. Dimana pelaku dijerat dengan Pasal 303 ayat (1) butir 2 KUHP Jo Pasal 2 ayat (1) Undang-undang Nomor 7 Tahun 1974 Tentang Penertiban Perjudian oleh Majelis Hakim dengan menjatuhkan pidana kepada Terdakwa tersebut, dengan pidana penjara selama 9 (Sembilan) bulan (Putusan Pengadilan Nomor 94/Pid.B/2017/PN.Gin).

Berdasarkan putusan Hakim mengenai kasus pembantuan dalam tindak pidana perjudian dalam hal dengan sengaja memberikan kesempatan kepada khalayak umum untuk bermain judi, dimana Hakim sudah sesuai menjatuhkan terdakwa I NYOMAN SUKARMA alias KARMA dengan Pasal 303 ayat (1) butir 2 yang telah memenuhi unsur-unsur dari pasal tersebut. Memang putusan yang dijatuhkan Hakim kepada terdakwa sudah sesuai dengan aturan yang berlaku, tetapi sanksi yang diberikan tidak juga memberikan efek jera terhadap terdakwa untuk tidak lagi mengulangi perbuatan pidana apapun, melihat terdakwa telah melakukan perbuatan pidana lebih dari sekali residivis. Seharusnya pemberian sanksi memberikan efek jera terhadap terdakwa untuk tidak mengulangi perbuatan pidana atau kejahatan-kejahatan lainnya.

\section{Simpulan}

Pembantuan sebagai salah satu bentuk tindak pidana diatur dalam Pasal 56 KUHP mengenai bentuk dari pembantuan, Pasal 57 KUHP mengenai pertanggungjawaban bagi pembantu kejahatan, dan Pasal 60 KUHP mengenai penegasan pertanggungjawaban pembantuan. Dalam KUHP yang dimaksud pembantu adalah mereka yang dengan sengaja memberi bantuan berupa memberi kesempatan, sarana atau keterangan untuk melakukan suatu perbuatan kejahatan pada saat sebelum dan saat dilakukannya kejahatan tersebut.

Hakim dalam memberikan sanksi pidana terhadap pelaku pembantuan dalam tindak pidana perjudian dengan nomor perkara 94/
Pid.B/2017/PN.Gin sudah sesuai dengan dikenakan Pasal 303 ayat (1) butir 2 KUHP. Dimana Hakim berpendapat bahwa I NYOMAN SUKARMA alias KARMA selaku pelaku telah memenuhi unsur dan terbukti secara sah telah melakukan pembantuan dalam tindak pidana perjudian dan menjatuhkan pidana terhadap pelaku dengan pidana penjara 9 (sembilan) bulan.

\section{Daftar Bacaan}

Ariman, H. M. R., \& Raghib, F. (2015). Hukum Pidana. Malang: Setara Press.

Burlian, P. (2016). Patologi Sosial. Jakarta: PT. Bumi Aksara.

Djamali, R. A. (2014). Pengantar Hukum Indonesia. Jakarta: Rajawali Pers.

Ebenezer, I., SibagariangSagala, M. J. P., Sari, I. C., Ebenezer, I., Sibagariang, \& Butarbutar, T. (2019). Tinjauan Yuridis Terhadap Tindak Pidana Permainan Judi Jackpot (Studi Kasus Putusan Nomor 45/Pid.B/2017/PN.MDN). JURNAL HUKUM KAIDAH Media Komunikasi Dan Informasi Hukum Dan Masyarakat, 18(3). Retrieved from https://jurnal.uisu.ac.id/index.php/jhk/ article/view/1205

Ikhsan, M. (2015). Faktor-Faktor Penyebab Terjadinya Perjudian Online Melalui Mediainternet Yang Dilakukan Oleh Mahasiswa Di Kota Pontianak Ditinjau Dari Sudut Kriminologi. Gloria Y uris Jurnal Hukum, 3(3). Retrieved from https://jurnal.untan.ac.id/index.php/ jmfh/article/view/9899

Kartono, K. (2015). Sosial Patalogi Jilid 1. Jakarta: Rajawali Pers.

Marpaung, L. (1991). Unsur-Unsur Perbuatan Yang Dapat Dihukum. Jakarta: Sinar Grafika.

Perjudian. (2018). Retrieved September 27, 2018, from https://id.wikipedia.org/ wiki/Perjudian/

Prasetyo, T. (2016). Hukum Pidana. Jakarta: PT Raja Grafindo Persada. 